\title{
Pemetaan Area Risiko Sanitasi Sektor Air Limbah Domestik Kota Cimahi
}

\author{
Heksantia Rahmadinda Yasya ${ }^{1}$, Iwan Juwana ${ }^{2}$ \\ ${ }^{1,2}$ Jurusan Teknik Lingkungan, Fakultas Teknik Sipil dan Perencanaan, Institut Teknologi Nasional, Bandung
}

*Koresponden email: diinda.yasya @gmail.com

Diterima: 12 Agustus 2019

Disetujui: 26 September 2019

\begin{abstract}
Cimahi is one of developing cities in Indonesia that has sanitation condition with low services, especially in domestic wastewater management. In 2016, the coverage of domestic wastewater services in the city only reached $68.17 \%$. In consequences, some communities discharging their wastewater to the stream. This matter could lead to water pollution that would indirectly affecting public health. Based on these problems, this reserach was carried out to calculate the level of risk in each urban village of Cimahi. The risk level is stated in the form of scores (1-4) with a description of 1 is very low risk; 2 is low risk; 3 is high risk; 4 very high risk. The risk calculation considers the determinants (exposure and impact) which consist of percentage of wastewater service, risk index, perceptions of related regional organizations, population, population density, poverty rates, and regional categories. The results obtained from the calculation of the risk of domestic wastewater in Cimahi show that the Pasirkaliki, Cibabat, Citeureup, Cipageran, Baros, and Cibeber have a very low risk; Cimahi and Utama are at low risk; Karangmekar, Cigugur Tengah and Cibeureum are at high risk; Padasuka, Setiamanah, Leuwigajah and Melong have a very high risk.
\end{abstract}

Keywords: Domestic Wastewater, Risk Score, Exposure Factor, Impact Factor, Risk Area

\begin{abstract}
Abstrak
Cimahi merupakan salah satu kota berkembang di Indonesia yang memiliki kondisi sanitasi dengan pelayanan rendah, terutama dalam hal pengelolaan air limbah domestik. Pada tahun 2016, cakupan pelayanan air limbah domestik di kota tersebut baru mencapai 68,17\%. Sebagai akibatnya, beberapa masyarakat membuang air limbah mereka ke sungai. Hal ini menyebabkan pencemaran air yang secara tidak langsung akan mempengaruhi kesehatan masyarakat. Berdasarkan permasalahan tersebut, penelitian ini dilakukan untuk menghitung tingkat risiko di setiap kelurahan Kota Cimahi. Tingkat risiko tersebut dinyatakan dalam bentuk skor (1-4) dengan keterangan 1 risiko sangat rendah; 2 risiko rendah; 3 risiko tinggi; 4 risiko sangat tinggi. Perhitungan risiko tersebut mempertimbangkan faktor penentu (exposure dan impact) yang terdiri dari persentase cakupan pelayanan, indeks risiko, persepsi OPD terkait, populasi penduduk, kepadatan penduduk, angka kemiskinan, dan kategori wilayah. Hasil yang didapat dari perhitungan risiko air limbah domestik di Kota Cimahi menunjukkan Kelurahan Pasirkaliki, Cibabat, Citeureup, Cipageran, Baros, dan Cibeber berisiko sangat rendah; Kelurahan Cimahi dan Utama berisiko rendah, Kelurahan Karangmekar, Cigugur Tengah, dan Cibeureum berisiko tinggi; serta Kelurahan Padasuka, Setiamanah, Leuwigajah, dan Melong berisiko sangat tinggi.
\end{abstract}

Kata Kunci: Air Limbah Domestik, Skor Risiko, Faktor Exposure, Faktor Impact, Area Berisiko

\section{Pendahuluan}

Kehidupan manusia di bumi tidak hanya menyangkut hubungan-hubungan sosial antar makhluk hidup, tetapi juga dengan lingkungan tempat makhluk hidup tersebut tinggal. Sering kita dengar salah satu hal yang diperhatikan dalam mencapai kesejahteraan hubungan manusia dengan lingkungannya dinyatakan dalam aspek sanitasi. Menurut Kamus Besar Bahasa Indonesia (KBBI), sanitasi merupakan usaha untuk membina dan menciptakan suatu keadaan di bidang kesehatan, terutama kesehatan masyarakat. Dalam Peraturan Pemerintah Nomor 66 Tahun 2014, sanitasi diartikan sebagai upaya pencegahan penurunan kualitas media lingkungan dan upaya peningkatan kualitas lingkungan. Adapun pengertian sanitasi lingkungan dalam KBBI tersebut adalah cara menyehatkan lingkungan hidup manusia terutama lingkungan fisik, yaitu tanah, air, dan udara. Sofyan dkk. (2014) menyebutkan bahwa sanitasi merupakan 
salah satu aspek dalam melakukan pembangunan yang menjadi kebutuhan dasar bagi manusia. Salah satu kebijakan pembangunan sanitasi di Indonesia mengacu kepada kebutuhan masyarakat (demand driven), tidak hanya bersifat target teknis semata (supply-driven).

Namun, penelitian menunjukkan bahwa kondisi sanitasi di Indonesia mencapai titik kritis. Pencapaian target sanitasi MDGs pun Indonesia menggambarkan kemajuan yang tidak begitu berarti. Pencapaian tersebut masih berada di bawah rata-rata jika dibandingkan dengan pencapaian negara-negara lainnya. Bahkan, pada tahun 2004 cakupan pelayanan sanitasi di Indonesia hanya mencapai 55\% yang merupakan pelayanan terendah di antara negara-negara Asia Tenggara (Adhi, 2009). Salah satu kota di Indonesia yang kini sedang berada pada fase perkembangan adalah Kota Cimahi, Jawa Barat. Kondisi sanitasi Kota Cimahi masih terbilang cukup rendah, terutama dalam pengelolaan air limbah domestik. Cakupan pelayanan air limbah domestik di kota tersebut baru mencapai 68,17\% (Oche, 2016). Dampak utamanya adalah tingkat pencemaran pada badan air masih tinggi yang tentu akan merugikan masyarakat itu sendiri. Salah satu bentuk dampak dari pencemaran tersebut digambarkan dengan profil kesehatan masyarakat Kota Cimahi (Sutarjo, 2018).

Melihat adanya dampak serius dari permasalahan ini, maka diperlukan suatu strategi yang dapat mengendalikan sistem sanitasi di Kota Cimahi untuk mencapai kesejahteraan masyarakatnya. Untuk merencanakan strategi secara cermat sehingga dapat mencapai tujuan tesebut, perlu identifikasi terlebih dulu tingkat risiko yang dialami setiap kelurahan di kota tersebut. Identifikasi tingkat risiko dilakukan dengan mempertimbangkan beberapa faktor yang saling berkaitan dengan risiko sanitasi sektor air limbah domestik. Pemetaan area sesuai tingkat risikonya dilakukan untuk memudahkan perencanaan strategis dan tepat sasaran.

\section{Metodologi Penelitian}

\subsection{Penentuan Bobot Faktor Exposure dan Faktor Impact}

Pembobotan dilakukan untuk menentukan tingkat prioritas dari setiap faktor exposure dan faktor impact. Faktor exposure merupakan elemen yang terpapar risiko, terdiri dari cakupan pelayanan air limbah domestik, indeks risiko sektor air limbah domestik (hasil studi EHRA), dan persepi dari Organisasi Perangkat Daerah (OPD) terkait. Sedangkan faktor impact adalah elemen-elemen yang turut berpengaruh dan berkaitan dengan faktor exposure, terdiri dari populasi penduduk, kepadatan penduduk, angka kemiskinan, dan kategori wilayahPenentuan prioritas ini didasari atas kepentingan dan kontribusi faktor-faktor tersebut terhadap penentuan risiko air limbah domestik secara keseluruhan. Metode yang digunakan dalam pembobotan ini adalah Analytical Hierarchy Process (AHP) karena dianggap sebagai metode yang sederhana dan mudah digunakan untuk menentukan prioritas (Saaty, 1986).

\subsection{Perhitungan Skor Risiko Berdasarkan Faktor Exposure}

Perhitungan skor risiko berdasarkan faktor exposure mencakup perhitungan cakupan pelayanan, indeks risiko, dan persepsi OPD terkait untuk setiap kelurahan di Kota Cimahi. Faktor exposure pertama, cakupan pelayanan, dapat dihitung dengan persamaan berikut (Hartoyo, 2018):

$\%$ pelayanan $=\frac{\text { Jumlah KK terlayani }}{\text { Jumlah KK total }} \times 100 \%$

Kemudian faktor exposure kedua yaitu indeks risiko berdasarkan studi EHRA yang dihitung dengan menggunakan Persamaan 3 (Azhar, 2016). Namun sebelum melakukan studi perlu dilakukan penentuan sampel dengan menggunakan rumus Slovin (Persamaan 2) karena teknik pengambilan sampel yang diterapkan adalah cluster sampling. Persebaran sampel juga ditentukan berdsasarkan strata setiap kelurahan, sehingga kelurahan yang berada di strata yang sama akan memiliki indeks risiko yang sama pula. Mengacu pada Dokumen Panduan Praktis Pelaksanaan EHRA Tahun 2014, stratifikasi dilakukan dengan mempertimbangkan kepadatan penduduk, angka kemiskinan, Daerah Aliran Sungai (DAS), dan daerah rawan banjir (Aditama, 2014).

$\mathrm{n}=\frac{\mathrm{N}}{1-\mathrm{Ne}^{2}}$

Keterangan:

$\mathrm{n}=$ Jumlah sampel

$\mathrm{N}=$ Jumlah Populasi

$\mathrm{e}=$ Tingkat kesalahan $(\%)$ 
$\mathrm{n}=\% \mathrm{KK} \times \%$ Bobot sumber bahaya

Keterangan:

$\mathrm{n}=$ indeks risiko $(\%)$

$\% \mathrm{KK}=$ Persentase Kepala Keluarga yang terpapar bahaya

Perlu diketahui bahwa dalam pelaksanaan studi EHRA untuk mendapatkan indeks risiko sanitasi sektor air limbah domestik, digunakan Dokumen "Panduan Praktiks Pelaksanaan EHRA 2014" yang diterbitkan oleh Kementerian Kesehatan Republik Indonesia. Dalam panduan tersebut, penilaian risiko air limbah domestik melalui studi EHRA mencakup tiga aspek yang perlu dipertimbangkan: pembuangan air limbah rumah tangga, sumber air bersih rumah tangga, dan Perilaku Hidup Bersih dan Sehat (PHBS) atau higiene. Dari masing-masing aspek tersebut, ditentukan variabel-variabel sumber bahaya yang berpotensi meningkatkan indeks risiko (AMPL, 2013).

Kemudian untuk faktor exposure ketiga yaitu persepsi dari OPD terkait, hanya dilakukan perhitungan modus, yaitu skor risiko yang paling banyak diberikan berdasarkan persepsi beberapa OPD.

Setelah ketiga faktor tersebut dihitung, kemudian perlu dilakukan normalisasi data untuk mengkonversi menjadi bentuk skor dan menghindari terjadinya inkonsistensi data (Achmad, 2018). Rumus yang digunakan untuk menghitung skor risiko faktor-faktor tersebut dapat dilihat pada Persamaan 4 dan Persamaan 5 (Hartoyo, 2018).

Skor risiko \% cakupan pelayanan :

Skor 1 , jika $\mathrm{X}>\mathrm{B}+0,75 \mathrm{C}$

Skor 2, jika $X>B+0,5 \mathrm{C}$

Skor 3, jika $\mathrm{X}>\mathrm{B}+0,25 \mathrm{C}$

Skor 4, jika $\mathrm{X}<\mathrm{B}+0,25 \mathrm{C}$

Skor risiko untuk faktor selain \% cakupan pelayanan:

Skor 1, jika $X<B+0,25 C$

Skor 2, jika $X>B+0,25 C$

Skor 3, jika $\mathrm{X}>\mathrm{B}+0,5 \mathrm{C}$

Skor 4, jika X > B+0,75C

Keterangan:

$\mathrm{X}=$ Data yang akan dikonversi menjadi skor

$\mathrm{B}=$ Nilai minimum dalam deret data tersebut

$\mathrm{C}=$ Nilai interval (nilai maksimum- nilai minimum)

\subsection{Perhitungan Skor Risiko Berdasarkan Faktor Impact}

Sama seperti faktor exposure, faktor-faktor impact yang terdiri dari populasi penduduk, kepadatan penduduk, angka kemiskinan, dan kategori wilayah juga dihitung dengan langkah yang sama. Setiap perhitungan pun dilakukan untuk setiap kelurahan di area studi ini. Berikut persamaan-persamaan yang digunakan dalam tahap ini:

Populasi penduduk $=\frac{\text { Jumlah penduduk kelurahan }}{\text { Jumlah penduduk kota }} \times 100 \%$

Kepadatan penduduk $=\frac{\text { Jumlah penduduk }(\mathrm{jiwa})}{\text { Luas area terbangun }(\mathrm{Ha})}$

Angka kemiskinan $=\frac{\text { Jumlah KK miskin }}{\text { Jumlah KK kelurahan }} \times 100 \%$

Kategori wilayah $=$ Skor 1 (jika perdesaan), skor 2 (jika perkotaan) 
Setelah keempat faktor dihitung berdasarkan persamaan-persamaan di atas, dilakukan normalisasi data menjadi bentuk skor dengan menggunakan Persamaan 5 (hanya berlaku untuk faktor populasi penduduk, kepadatan penduduk, dan angka kemiskinan).

\subsection{Perhitungan Skor Risiko Air Limbah Domestik}

Pada penelitian ini, skor risiko yang akan dipetakan merupakan skor akhir yang merupakan hasil perkalian antara skor akhir faktor exposure dengan skor akhir faktor impact. Sebelum perkalian dua faktor tersebut, masing-masing elemen dikalikan sesuai dengan bobot yang telah ditetapkan dengan metode AHP. Berikut tahapan dan persamaan yang diterapkan pada perhitungan ini:

Skor exposure $=(\mathrm{E} 1 \times \mathrm{B} 1)+(\mathrm{E} 2 \times \mathrm{B} 2)+(\mathrm{E} 3 \times \mathrm{B} 3)$

\section{Keterangan:}

$\mathrm{E} 1=$ Skor risiko berdasarkan \% cakupan pelayanan

$\mathrm{E} 2=$ Skor risiko berdasarkan indeks risiko (Studi EHRA)

E3 $=$ Skor risiko berdasarkan persepsi OPD

$\mathrm{B} 1=$ Bobot $\%$ cakupan pelayanan $(\%)$

$\mathrm{B} 2=$ Bobot indeks risiko $(\%)$

$\mathrm{B} 3=$ Bobor persepsi OPD $(\%)$

Skor impact $=(\mathrm{I} 1 \times \mathrm{B} 4)+(\mathrm{I} 2 \times \mathrm{B} 5)+(\mathrm{I} 3 \times \mathrm{B} 6)+(\mathrm{I} 4 \times \mathrm{B} 7)$

Keterangan:

I1 $=$ Skor risiko berdasarkan populasi penduduk

I2 = Skor risiko berdasarkankepadatan penduduk

I3 = Skor risiko berdasarkan angka kemiskinan

I4 = Skor risiko berdasarkan kategori wilayah

B4 = Bobot populasi penduduk $(\%)$

B5 $=$ Bobot kepadatan pendudk $(\%)$

B6 $=$ Bobot angka kemiskinan $(\%)$

B7 $=$ Bobot kategori wilayah $(\%)$

Maka berdasarkan perhitungan yang telah dilakukan tersebut, skor akhir air limbah domestik dapat ditentukan dengan menggunakaan Persamaan 11 berikut:

Skor air limbah domestik $=$ Skor exposure $\mathrm{x}$ Skor impact

Catatan penting dalam perhitungan ini yaitu normalisasi data harus dilakukan di setiap akhir perhitungan skor. Pada tahap ini, normalisasi dilakukan setelah mendapat skor exposure, setelah mendapat skor impact, serta setelah mengalikan antara skor exposure dengan skor impact. Normalisasi ini masih mengacu pada rumus yang sama, yaitu Persamaan 5.

\section{Hasil dan Pembahasan}

\subsection{Penentuan Bobot Faktor Exposure dan Faktor Impact}

Pembobotan yang dilakukan dengan metode AHP untuk kedua faktor penentuan ini diawali dengan penyusunan hierarki sebagai dasar proses analisis. Hierarki disusun secara terpisah untuk faktor exposure dan faktor impact. Tingkatan dalam hierarki yang disusun pada tahap ini dapat dilihat pada Gambar 1 dan Gambar 2.

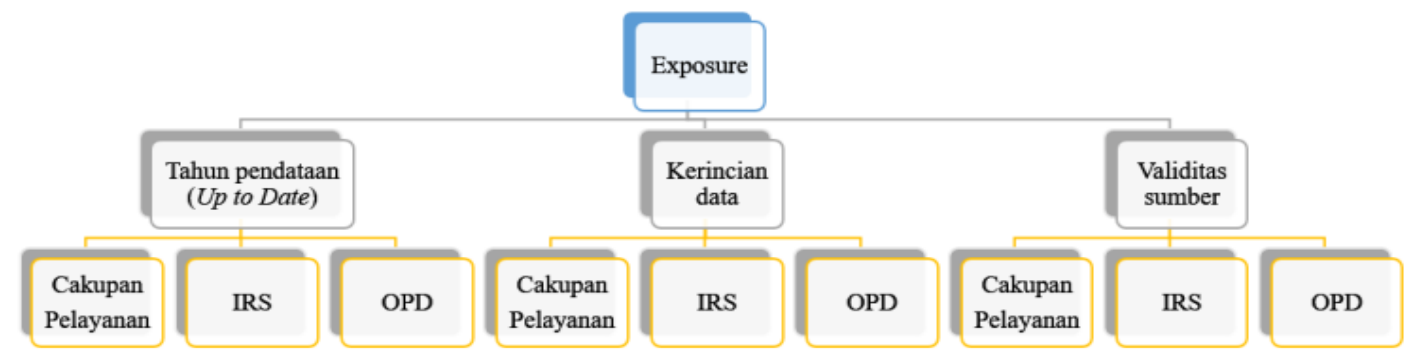

Gambar 1. Hierarki analitik Faktor Exposure 


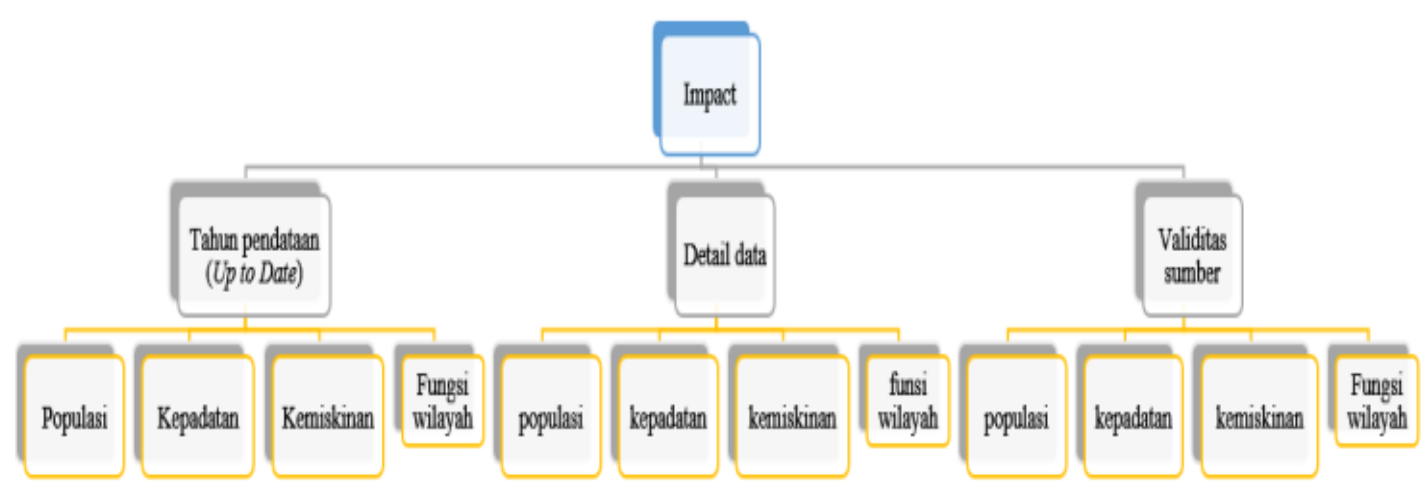

Gambar 2. Hierarki analitik Faktor Impact

Dengan mengikuti rangkaian tahap analisis menggunakan metode AHP, hasil pembobotan untuk setiap faktor penentu di atas dapat dilihat pada Tabel 1. dan Tabel 2.

Tabel 1. Bobot Faktor Exposure

\begin{tabular}{lc}
\hline \multicolumn{1}{c}{ Faktor } & Bobot \\
\hline Cakupan Pelayanan & $51 \%$ \\
IRS-EHRA & $23 \%$ \\
Persepsi OPD & $26 \%$ \\
\hline
\end{tabular}

Tabel 2. Bobot Faktor Impact

\begin{tabular}{lc}
\hline \multicolumn{1}{c}{ Faktor } & Bobot \\
\hline Populasi penduduk & $40 \%$ \\
Kepadatan penduduk & $20 \%$ \\
Angka Kemiskinan & $30 \%$ \\
Fungsi Urban & $10 \%$ \\
\hline
\end{tabular}

\subsection{Perhitungan Skor Risiko Berdasarkan Faktor Exposure}

Faktor exposure pertama yang dihitung adalah cakupan pelayanan dalam bentuk persentase yang kemudian dilakukan konversi menjadi skor dengan Persamaan 4. Berdasarkan data cakupan pelayanan air limbah domestik Kota Cimahi (Dinas Perumahan dan Kawasan Permukiman Kota Cimahi, 2017), hasil perhitungan skor risiko dapat dilihat pada Tabel 3.

Tabel 3. Skor risiko berdasarkan cakupan pelayanan air limbah domestik

\begin{tabular}{lll}
\hline \multicolumn{1}{c}{ Kelurahan } & Cakupan Pelayanan & Skor \\
\hline Pasirkaliki & $92,91 \%$ & 1 \\
Cibabat & $79,13 \%$ & 2 \\
Citeureup & $86,03 \%$ & 1 \\
Cipageran & $85,28 \%$ & 1 \\
Baros & $88,47 \%$ & 1 \\
Cigugur Tengah & $78,77 \%$ & 2 \\
Karang Mekar & $81,03 \%$ & 2 \\
Setiamanah & $61,44 \%$ & 4 \\
Padasuka & $74,21 \%$ & 3 \\
Cimahi & $80,99 \%$ & 2 \\
Melong & $74,05 \%$ & 3 \\
Cibeureum & $78,20 \%$ & 2 \\
Utama & $67,70 \%$ & 4 \\
Leuwigajah & $75,95 \%$ & 3 \\
Cibeber & $87,70 \%$ & 1 \\
Nilai maks. & $92,91 \%$ & - \\
Nilai min. & $61,44 \%$ & - \\
\hline Interval & $31,47 \%$ & - \\
\hline
\end{tabular}


Kemudian untuk faktor exposure kedua, indeks risiko, didapat dari hasil studi EHRA dengan jumlah sampel sebesar $100 \mathrm{KK}$ (tingkat kesalahan 10\%). Berdasarkan hasil stratifikasi kelurahan dan penetapan variabel sumber bahaya tiap aspek. Tabel 4. menunjukkan persentase jumlah KK setiap strata yang terpapar sumber bahaya:

Tabel 4. Indeks Risiko sanitasi sektor air limbah domestik

\begin{tabular}{|c|c|c|c|c|c|c|c|}
\hline \multirow{3}{*}{ Variabel } & \multirow{3}{*}{ Jawaban } & \multicolumn{6}{|c|}{ Strata } \\
\hline & & \multicolumn{2}{|c|}{2} & \multicolumn{2}{|c|}{3} & \multicolumn{2}{|c|}{4} \\
\hline & & $\mathrm{n}$ & $\%$ & $\mathrm{n}$ & $\%$ & $\mathrm{n}$ & $\%$ \\
\hline \multicolumn{8}{|l|}{ Air Limbah Domestik } \\
\hline 1. Tempat BAB & $\begin{array}{l}\text { Selain jamban pribadi } \\
\text { dan MCK/MCK umum }\end{array}$ & 0 & 0 & 0 & 0 & 0 & 0 \\
\hline 2. Memiliki jamban & Tidak & 0 & 0 & 1 & 3 & 0 & 0 \\
\hline 3. Jenis jamban & Selain kloset & 0 & 0 & 0 & 0 & 0 & 0 \\
\hline 4. Pembuangan tinja & $\begin{array}{l}\text { Selain tangki septik dan } \\
\text { pipa sewer }\end{array}$ & 16 & 40 & 11 & 28 & 14 & 70 \\
\hline \multicolumn{8}{|l|}{ Sumber Air } \\
\hline 1. Sumber air minum & Sumber tidak terlindungi & 0 & 0 & 1 & 3 & 0 & 0 \\
\hline 2. Sumber air masak & Sumber tidak terlindungi & 0 & 0 & 2 & 5 & 0 & 0 \\
\hline 3. Sumber air cuci piring & Sumber tidak terlindungi & 0 & 0 & 2 & 5 & 0 & 0 \\
\hline 4. Sumber air gosok gigi & Sumber tidak terlindungi & 0 & 0 & 2 & 5 & 0 & $0 \%$ \\
\hline 5. Kelangkaan air bersih & Pernah & 6 & 15 & 7 & 18 & 7 & 35 \\
\hline 6. Kualitas air & Tidak puas & 0 & 0 & 4 & 10 & 0 & 0 \\
\hline 7. Tempat menyimpan air & $\begin{array}{l}\text { Selain tidak disimpan, di } \\
\text { panci tertutup, termos, } \\
\text { teko, galon }\end{array}$ & 1 & 3 & 1 & 3 & 0 & 0 \\
\hline \multicolumn{8}{|l|}{ Perilaku Higiene } \\
\hline $\begin{array}{l}\text { 1. Tidak Cuci Tangan Pa- } \\
\text { kai Sabun (CTPS) di } \\
\text { waktu penting }\end{array}$ & $\begin{array}{l}\text { Selain: setelah BAB, } \\
\text { setelah cebokin anak, } \\
\text { sebelum makan, sebelum } \\
\text { nyuapin, sebelum masak, } \\
\text { sesudah memegang he- } \\
\text { wan) }\end{array}$ & 26 & 65 & 26 & 65 & 7 & 35 \\
\hline 2. Diare & Ya/pernah & 11 & 28 & 7 & 18 & 0 & 0 \\
\hline
\end{tabular}

Kemudian setelah melakukan perhitungan di atas, dilanjutkan dengan kalkulasi indeks risiko berdasarkan persentase yang telah didapat. Kalkulasi ini dihitung dengan mengalikan persentase KK terpapar bahaya dengan bobot dari masing-masing sumber bahaya (Tabel 5). Pembobotan diperlukan untuk menggambarkan sumber bahaya yang paling berkontribusi dalam peningkatan indeks risiko atau penurunan kualitas lingkugan. 
Tabel 5. Kalkulasi indeks risiko

\begin{tabular}{|c|c|c|c|c|}
\hline \multirow{3}{*}{ Variabel } & \multirow{3}{*}{ Bobot } & \multicolumn{3}{|c|}{$\begin{array}{c}\text { Persentase } \mathrm{n} \\
(\%)\end{array}$} \\
\hline & & \multicolumn{3}{|c|}{ Strata } \\
\hline & & 2 & 3 & 4 \\
\hline Air Limbah Domestik & & 12 & 9 & 21 \\
\hline Tempat BAB & $30 \%$ & 0 & 0 & 0 \\
\hline Tidak memiliki jamban & $10 \%$ & 0 & 0 & 0 \\
\hline Jenis jamban (selain kloset) & $30 \%$ & 1 & 0 & 0 \\
\hline $\begin{array}{l}\text { Pembuangan tinja (selain TS } \\
\text { dan pipa sewer) }\end{array}$ & $30 \%$ & 12 & 8 & 21 \\
\hline Sumber Air & & 5 & 9 & 11 \\
\hline Sumber air minum & $10 \%$ & 0 & 0 & 0 \\
\hline Sumber air masak & $10 \%$ & 0 & 1 & 0 \\
\hline Sumber air cuci piring & $10 \%$ & 0 & 1 & 0 \\
\hline Sumber air gosok gigi & $10 \%$ & 0 & 1 & 0 \\
\hline Kelangkaan air bersih & $30 \%$ & 5 & 5 & 11 \\
\hline Kepuasan terhadap kualitas air & $10 \%$ & 0 & 1 & 0 \\
\hline Tempat menyimpan air & $20 \%$ & 1 & 1 & 0 \\
\hline Perilaku Higiene & & 46 & 41 & 18 \\
\hline Tidak CTPS di 5 waktu penting & $50 \%$ & 33 & 33 & 18 \\
\hline Diare & $50 \%$ & 14 & 9 & 0 \\
\hline
\end{tabular}

Berikutnya, tahap terakhir dalam melakukan perhitungan indeks risiko yaitu mengakumulasi nilainilai indeks (\%) yang telah dibobotkan untuk setiap aspek (air limbah, sumber air bersih, dan higiene). Karena dalam studi EHRA ini pengelompokkan sampel didasari atas perbedaan strata, maka indeks risiko yang didapat bernilai sama untuk semua kelurahan yang berada di satu strata (Tabel 6).

Tabel 6. Kumulatif indeks risiko

\begin{tabular}{cccc}
\hline \multirow{2}{*}{ Sektor Sanitasi } & \multicolumn{3}{c}{ Jumlah KK $(\%)$} \\
\cline { 2 - 4 } & 2 & 3 & 4 \\
\cline { 2 - 4 } & 12 & 9 & 21 \\
Air Limbah Domestik & 5 & 9 & 11 \\
Sumber Air & 46 & 41 & 18 \\
Perilaku Higiene & &
\end{tabular}

Nilai yang diperhitungkan dalam scoring tingkat risiko merupakan akumulasi indeks risiko berdasarkan tiga aspek, seperti yang dapat dilihat pada Tabel 7.

Tabel 7. Skor risiko berdasarkan studi EHRA

\begin{tabular}{lcc}
\hline \multicolumn{1}{c}{ Kelurahan } & $\begin{array}{c}\text { Akumulasi Indeks } \\
\text { Risiko }(\%)\end{array}$ & Skor \\
\hline Pasirkaliki & 63 & 4 \\
Cibabat & 59 & 3 \\
Citeureup & 63 & 4 \\
Cipageran & 63 & 4 \\
Baros & 63 & 4 \\
Cigugur Tengah & 50 & 1 \\
Karang Mekar & 59 & 3 \\
Setiamanah & 59 & 3 \\
Padasuka & 59 & 3 \\
Cimahi & 59 & 3 \\
Melong & 59 & 3 \\
\hline
\end{tabular}




\begin{tabular}{lcc}
\hline Kelurahan & $\begin{array}{c}\text { Akumulasi Indeks } \\
\text { Risiko }(\%)\end{array}$ & Skor \\
\hline Cibeureum & 50 & 1 \\
Utama & 50 & 1 \\
Leuwigajah & 63 & 4 \\
Cibeber & 63 & 4 \\
Nilai maks. & 63 & - \\
Nilai min. & 50 & - \\
Interval & 13 & - \\
\hline
\end{tabular}

Setelah melakukan perhitungan indeks risiko seperti yang sebelumnya dipaparkan, faktor exposure ketiga didapat berdasarkan wawancara dengan OPD terkait pengelolaan air limbah domestik. Persepsi yang diberikan berkisar satu sampai empat (1-4). Setelah dilakukan rekapitulasi, berikut skor risiko setiap kelurahan yang diberikan oleh beberapa OPD (Tabel 8.). Skor yang tercantum bukan hasil perhitungan, melainkan didapat langsung dari persepsi OPD.

Tabel 8. Skor risiko berdasarkan persepsi OPD

\begin{tabular}{clc}
\hline No. & \multicolumn{1}{c}{ Kelurahan } & Skor \\
\hline 1 & Pasirkaliki & 1 \\
2 & Cibabat & 1 \\
3 & Citeureup & 1 \\
4 & Cipageran & 1 \\
5 & Baros & 2 \\
6 & Cigugur Tengah & 2 \\
7 & Karang Mekar & 2 \\
8 & Setiamanah & 2 \\
9 & Padasuka & 1 \\
10 & Cimahi & 2 \\
11 & Melong & 2 \\
12 & Cibeureum & 2 \\
13 & Utama & 2 \\
14 & Leuwigajah & 2 \\
15 & Cibeber & 1 \\
\hline
\end{tabular}

\subsection{Perhitungan Skor Risiko Berdasarkan Faktor Impact}

Faktor pertama yang dihitung dalam tahap ini yaitu populasi penduduk. Populasi penduduk dihitung dengan Persamaan 6 sehingga menghasilkan nilai dalam bentuk persentase. Setelah dikonversi melalui normalisasi data, hasil skor risiko yang dihitung berdasarkan populasi penduduk di setiap kelurahan dapat dilihat Tabel 9.

Tabel 9. Skor risiko berdasarkan populasi penduduk

\begin{tabular}{lccc}
\hline \multicolumn{1}{c}{ Kelurahan } & $\begin{array}{c}\text { Jumlah } \\
\text { Penduduk } \\
\text { (jiwa) }\end{array}$ & $\begin{array}{c}\text { Persentase } \\
\text { Populasi } \\
\text { Penduduk } \\
(\%)\end{array}$ & Skor \\
\hline Pasirkaliki & 17.786 & $3,4 \%$ & 1 \\
Cibabat & 56.407 & $9,8 \%$ & 4 \\
Citeureup & 39.046 & $6,9 \%$ & 2 \\
Cipageran & 40.994 & $8,6 \%$ & 3 \\
Baros & 23.840 & $3,8 \%$ & 1 \\
Cigugur Tengah & 52.439 & $8,6 \%$ & 3 \\
Karang Mekar & 18.195 & $3,0 \%$ & 1 \\
Setiamanah & 24.763 & $4,2 \%$ & 1 \\
Padasuka & 42.481 & $7,1 \%$ & 3 \\
Cimahi & 12.048 & $2,4 \%$ & 1 \\
Melong & 72.120 & $11,7 \%$ & 4 \\
\hline
\end{tabular}




\begin{tabular}{lccc}
\hline \multicolumn{1}{c}{ Kelurahan } & $\begin{array}{c}\text { Jumlah } \\
\text { Penduduk } \\
\text { (jiwa) }\end{array}$ & $\begin{array}{c}\text { Persentase } \\
\text { Populasi } \\
\text { Penduduk } \\
(\%)\end{array}$ & Skor \\
\hline Cibeureum & 69.116 & $11,1 \%$ & 4 \\
Utama & 38.863 & $6,3 \%$ & 2 \\
Leuwigajah & 48.195 & $8,1 \%$ & 3 \\
Cibeber & 29.355 & $5,0 \%$ & 2 \\
Jumlah & 532.987 & - & - \\
Nilai Maks. & & $11,7 \%$ & - \\
Nilai Min. & & $2,4 \%$ & - \\
\hline Interval & & $9,3 \%$ & - \\
\hline
\end{tabular}

Setelah menghitung populasi penduduk beserta risiko yang ditimbulkan dalam bentuk skor, selanjutnya perhitungan kepadatan penduduk yang didapat dari perbandingan antara jumlah penduduk dengan luas area terbangun (Persamaan 7). Berikut hasil yang didapat dari perhitungan tersebut (Tabel 10):

Tabel 10. Skor Risiko Berdasarkan Kepadatan Penduduk

\begin{tabular}{lcc}
\hline \multicolumn{1}{c}{ Kelurahan } & $\begin{array}{c}\text { Kepadatan } \\
\text { Penduduk } \\
\text { (Jiwa/Ha) }\end{array}$ & Skor \\
\hline Pasirkaliki & 267 & 2 \\
Cibabat & 340 & 4 \\
Citeureup & 212 & 2 \\
Cipageran & 145 & 1 \\
Baros & 170 & 1 \\
Cigugur Tengah & 367 & 4 \\
Karang Mekar & 226 & 2 \\
Setiamanah & 308 & 3 \\
Padasuka & 358 & 4 \\
Cimahi & 285 & 3 \\
Melong & 374 & 4 \\
Cibeureum & 402 & 4 \\
Utama & 165 & 1 \\
Leuwigajah & 206 & 1 \\
Cibeber & 149 & 1 \\
Nilai Maks. & 402 & - \\
Nilai Min. & 145 & - \\
\hline Interval & 257 & - \\
\hline
\end{tabular}

Faktor ketiga dalam perhitungan ini yaitu angka kemiskinan yang didapat dari perbandingan antara jumlah KK miskin dengan jumlah KK total (Persamaan 8). Tabel 11. yang merupakan hasil rekapitulasi perhitungan tersebut:

Tabel 11. Skor Risiko Berdasarkan Angka Kemiskinan

\begin{tabular}{lcc}
\hline \multicolumn{1}{c}{ Kelurahan } & $\begin{array}{c}\text { Angka } \\
\text { Kemiskinan (\%) }\end{array}$ & Skor \\
\hline Pasirkaliki & $4,9 \%$ & 1 \\
Cibabat & $5,2 \%$ & 1 \\
Citeureup & $5,1 \%$ & 1 \\
Cipageran & $4,7 \%$ & 1 \\
Baros & $5,8 \%$ & 1 \\
Cigugur Tengah & $10,6 \%$ & 4 \\
\hline
\end{tabular}




\begin{tabular}{lcc}
\hline \multicolumn{1}{c}{ Kelurahan } & $\begin{array}{c}\text { Angka } \\
\text { Kemiskinan }(\%)\end{array}$ & Skor \\
\hline Karang Mekar & $7,9 \%$ & 3 \\
Setiamanah & $8,3 \%$ & 3 \\
Padasuka & $7,9 \%$ & 3 \\
Cimahi & $9,8 \%$ & 4 \\
Melong & $4,7 \%$ & 1 \\
Cibeureum & $10,9 \%$ & 4 \\
Utama & $8,1 \%$ & 3 \\
Leuwigajah & $6,9 \%$ & 2 \\
Cibeber & $6,3 \%$ & 2 \\
Nilai Maks. & $10,9 \%$ & - \\
Nilai Min. & $4,7 \%$ & - \\
\hline Interval & $6,3 \%$ & - \\
\hline
\end{tabular}

Berbeda dengan perhitungan data populasi, kepadatan, dan angka kemiskinan, skor berdasarkan kategori atau fungsi wilayah ini tidak didapat berdasarkan perhitungan. Seperti yang telah disebutkan dalam Bagian 2. Metodologi, skor risiko dapat langsung diberikan hanya dengan mengidentifikasi kelurahan tersebut berdasarkan kategori urban/rural. Jika suatu kelurahan termasuk kategori perkotaan, maka diberi skor 2, sedangkan jika suatu kelurahan termasuk kateogiru perdesaan, maka diberi skor 1. Mengacu pada Peraturan Kepala Badan Pusat Statistik Nomor 37 Tahun 2010 tentang Klasifikasi Perkotaan dan Perdesaan di Indonesia, diketahui 15 kelurahan di Kota Cimahi termasuk dalam kategori perkotaan sehingga semua kelurahan diberi skor 2.

\subsection{Perhitungan Skor Risiko Air Limbah Domestik}

Berdasarkan perhitungan skor exposure dan skor impact, rekapitulasi perhitungan berdasarkan Persamaan 9 untuk skor exposure dan Persamaan 10 untuk skor impact dapat dilihat pada Tabel 9 dan Tabel 10. Sedangkan skor air limbah domestik yang didapat dari hasil perkalian skor exposure dan skor impact dapat dilihat pada Tabel 11. Perkalian antara kedua faktor tersebut menunjukkan bahwa elemen yang berisiko dan elemen yang berkaitan dengan risiko tersebut berbanding lurus. Semakin besar risiko yang diterima suatu kelurahan (faktor exposure), maka akan semakin besar pula risiko pengelolaan air limbah domestik yang digambarkan secara keseluruhan.

Sebagai contoh, cakupan pelayanan air limbah domestik yang masih rendah dapat mewakili bahwa pengelolaan air limbah di kelurahan tersebut memiliki risiko. Begitu pun dari faktor impact, jika dikatakan suatu kelurahan terlalu padat penduduk, maka pengelolaan air limbah domestik pun memiliki risiko karena seharunya pengelolaan juga dapat diterapkan pada berbagai kondisi wilayah dan masyarakatnya. Jika dalam kasus tertentu seperti Kelurahan Cigugur Tengah yang memiliki perbedaan signifikan antara skor exposure dan skor impact, dapat diartikan bahwa cakupan pelayanan air limbah domestik sudah baik, akan tetapi jika dilihat dari faktor penentu impact, Cigugur Tengah masih berisiko. Dengan kata lain, walaupun pelayanan di kelurahan tersebut sudah baik, tetapi tidak menutup kemungkinan kelurahan tersebut masih berisiko karena kepadatan penduduk dan kemiskinannya masih tinggi.

Tabel 12. Skor Faktor Exposure

\begin{tabular}{lccccc}
\hline \multirow{2}{*}{ Kelurahan } & $\begin{array}{c}\text { Cakupan } \\
\text { Pelayanan }\end{array}$ & $\begin{array}{c}\text { Persepsi } \\
\text { SKPD }\end{array}$ & $\begin{array}{c}\text { IRS } \\
\text { (Studi } \\
\text { EHRA) }\end{array}$ & $\begin{array}{c}\text { Total } \\
\text { Skor }\end{array}$ & $\begin{array}{c}\text { Skor } \\
\text { Exposure }\end{array}$ \\
\cline { 2 - 4 } & $51 \%$ & $26 \%$ & $23 \%$ & & \\
\cline { 2 - 5 } Pasirkaliki & 1 & 1 & 4 & 1,7 & 1 \\
Cibabat & 2 & 1 & 3 & 2,0 & 1 \\
Citeureup & 1 & 1 & 4 & 1,7 & 1 \\
Cipageran & 1 & 1 & 4 & 1,7 & 1 \\
Baros & 1 & 2 & 4 & 2,0 & 1 \\
Cigugur & 2 & 2 & 1 & 1,8 & 1 \\
Tengah & & & & & \\
\hline
\end{tabular}




\begin{tabular}{lccccc}
\hline \multirow{2}{*}{ Kelurahan } & $\begin{array}{c}\text { Cakupan } \\
\text { Pelayanan }\end{array}$ & $\begin{array}{c}\text { Persepsi } \\
\text { SKPD }\end{array}$ & $\begin{array}{c}\text { IRS } \\
\text { (Studi } \\
\text { EHRA) }\end{array}$ & $\begin{array}{c}\text { Total } \\
\text { Skor }\end{array}$ & $\begin{array}{c}\text { Skor } \\
\text { Exposure }\end{array}$ \\
\cline { 2 - 4 } & $51 \%$ & $26 \%$ & $23 \%$ & & \\
\cline { 2 - 4 } Karang & 2 & 2 & 3 & 2,2 & 2 \\
Sekar & 4 & 2 & 3 & 3,3 & 4 \\
Padamanah & 3 & 1 & 3 & 2,5 & 3 \\
Cimahi & 2 & 2 & 3 & 2,2 & 2 \\
Melong & 3 & 2 & 3 & 2,7 & 3 \\
Cibeureum & 2 & 2 & 1 & 1,8 & 1 \\
Utama & 4 & 2 & 1 & 2,8 & 3 \\
Leuwigajah & 3 & 2 & 4 & 3,0 & 4 \\
Cibeber & 1 & 1 & 4 & 1,7 & 1 \\
Nilai Maks. & & & & 3,3 & \\
Nilai Min. & & & & 1,7 & \\
\hline Interval & & & & 1,6 & \\
\hline
\end{tabular}

Tabel 13. Skor Faktor Impact

\begin{tabular}{|c|c|c|c|c|c|c|}
\hline \multirow[t]{2}{*}{ Kelurahan } & $\begin{array}{l}\text { Popu- } \\
\text { lasi }\end{array}$ & $\begin{array}{l}\text { Kepadatan } \\
\text { Penduduk }\end{array}$ & $\begin{array}{l}\text { Angka } \\
\text { Kem- } \\
\text { iskinan }\end{array}$ & $\begin{array}{c}\text { Fungsi } \\
\text { Wilayah }\end{array}$ & \multirow[t]{2}{*}{$\begin{array}{l}\text { Total } \\
\text { Skor }\end{array}$} & \multirow[t]{2}{*}{$\begin{array}{c}\text { Skor } \\
\text { Impact }\end{array}$} \\
\hline & $38 \%$ & $20 \%$ & $32 \%$ & $10 \%$ & & \\
\hline Pasirkaliki & 1 & 2 & 1 & 2 & 1,3 & 1 \\
\hline Cibabat & 4 & 4 & 1 & 2 & 2,8 & 3 \\
\hline Citeureup & 2 & 2 & 1 & 2 & 1,7 & 1 \\
\hline Cipageran & 3 & 1 & 1 & 2 & 1,9 & 2 \\
\hline Baros & 1 & 1 & 1 & 2 & 1,1 & 1 \\
\hline Cigugur Tengah & 3 & 4 & 4 & 2 & 3,4 & 4 \\
\hline Karang Mekar & 1 & 2 & 3 & 2 & 1,9 & 2 \\
\hline Setiamanah & 1 & 3 & 3 & 2 & 2,1 & 2 \\
\hline Padasuka & 3 & 4 & 3 & 2 & 3,1 & 3 \\
\hline Cimahi & 1 & 3 & 4 & 2 & 2,5 & 3 \\
\hline Melong & 4 & 4 & 1 & 2 & 2,8 & 3 \\
\hline Cibeureum & 4 & 4 & 4 & 2 & 3,8 & 4 \\
\hline Utama & 2 & 1 & 3 & 2 & 2,1 & 2 \\
\hline Leuwigajah & 3 & 1 & 2 & 2 & 2,2 & 2 \\
\hline Cibeber & 2 & 1 & 2 & 2 & 1,8 & 2 \\
\hline Nilai Maksimum & & & & & 3,8 & \\
\hline Nilai Minimum & & & & & 1,1 & \\
\hline Nilai Interval & & & & & 2,7 & \\
\hline
\end{tabular}

Tabel 14. Skor risiko air limbah domestik Kota Cimahi

\begin{tabular}{lcccc}
\hline \multicolumn{1}{c}{ Kelurahan } & $\begin{array}{c}\text { Skor } \\
\text { Exposure }\end{array}$ & $\begin{array}{c}\text { Skor } \\
\text { Impact }\end{array}$ & $\begin{array}{c}\text { Total } \\
\text { Skor }\end{array}$ & Skor Air Limbah Domestik \\
\hline Pasirkaliki & 1 & 1 & 1 & 1 \\
Cibabat & 1 & 3 & 3 & 1 \\
Citeureup & 1 & 1 & 1 & 1 \\
Cipageran & 1 & 2 & 2 & 1 \\
Baros & 1 & 1 & 1 & 1 \\
\hline
\end{tabular}




\begin{tabular}{lcccc}
\hline \multicolumn{1}{c}{ Kelurahan } & $\begin{array}{c}\text { Skor } \\
\text { Exposure }\end{array}$ & $\begin{array}{c}\text { Skor } \\
\text { Impact }\end{array}$ & $\begin{array}{c}\text { Total } \\
\text { Skor }\end{array}$ & Skor Air Limbah Domestik \\
\hline Cigugur Tengah & 1 & 4 & 4 & 2 \\
Karang Mekar & 2 & 2 & 4 & 2 \\
Setiamanah & 4 & 2 & 8 & 4 \\
Padasuka & 3 & 3 & 9 & 4 \\
Cimahi & 2 & 3 & 6 & 3 \\
Melong & 3 & 3 & 9 & 4 \\
Cibeureum & 1 & 4 & 4 & 2 \\
Utama & 3 & 2 & 6 & 3 \\
Leuwigajah & 4 & 2 & 8 & 1 \\
Cibeber & 1 & 2 & 2 & \\
Nilai Maks. & & & 9 & \\
Nilai Min. & & & 1 & \\
\hline Interval & & & 8 & \\
\hline
\end{tabular}

Tabel 12, 13, dan 14 merupakan hasil rekapitulasi dari rangkaian perhitungan sebelumnya yang mempertimbangkan beberapa faktor. Jika skor risiko tersebut dinyatakan secara visual, maka dihasilkan pemetaan yang dapat dapat dilihat pada Gambar 3.

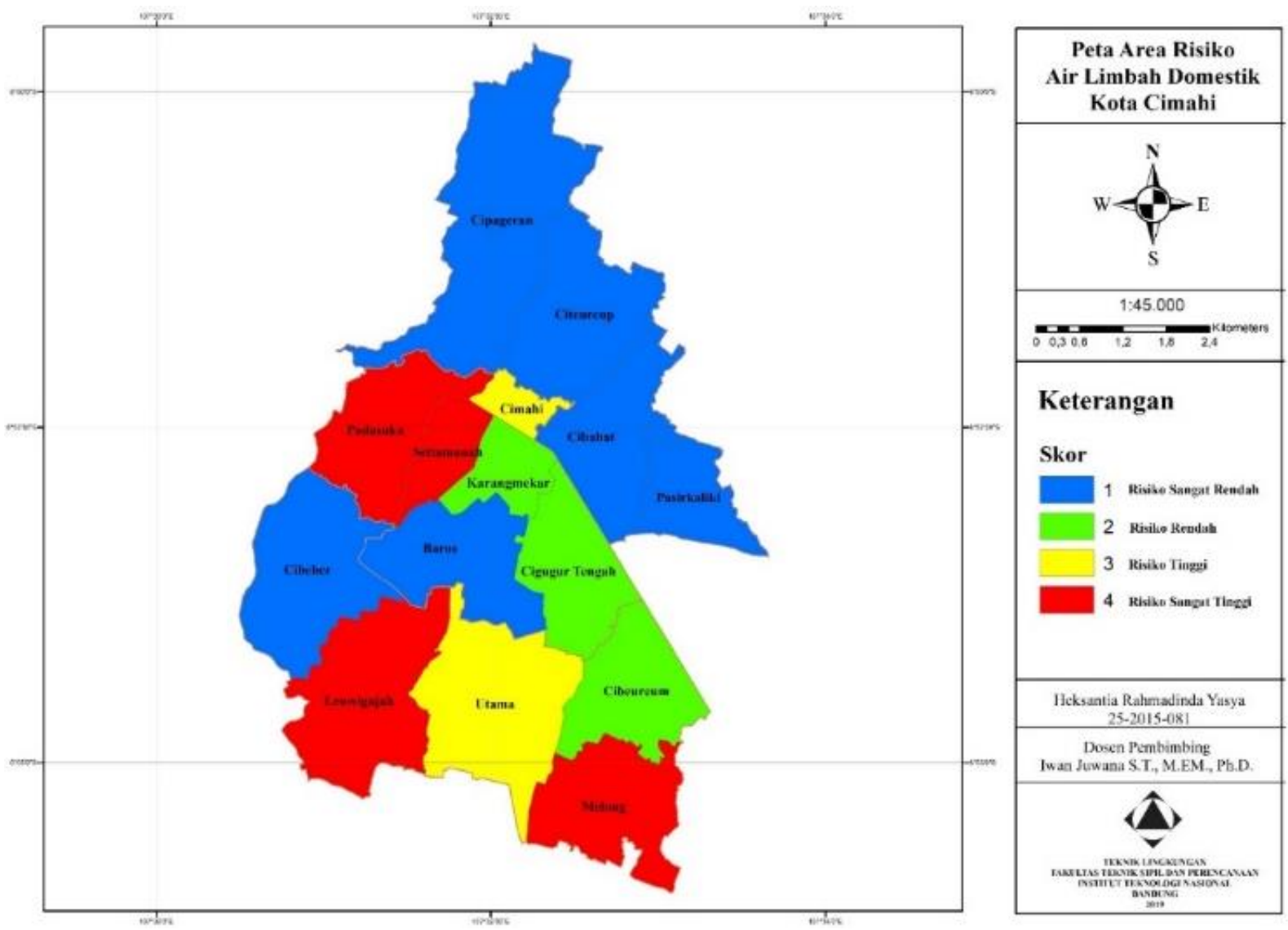

Gambar 3. Peta area berisiko sanitasi sektor air limbah domestik Kota Cimahi

\section{Kesimpulan}

Kota Cimahi terdiri dari 15 kelurahan dengan berbagai tingkat risiko yang berbeda. Berdasarkan pertimbangan faktor-faktor exposure dan faktor impact, perhitungan dilakukan secara bertahap dan saling berkaitan hingga menghasilkan tingkat risiko dalam bentuk skor (1-4). Terdapat enam kelurahan yang memiliki risiko sangat rendah, yaitu Kelurahan Pasirkaliki, Cibabat, Citeureup, Cipageran, Cibeber, dan Baros; tiga kelurahan berisiko rendah yaitu Kelurahan Karangmekar, Cigugur Tengah, dan Cibeureum; 
dua kelurahan berisiko tinggi yaitu Kelurahan Cimahi dan Utama; serta empat kelurahan berisiko sangat tinggi yaitu Kelurahan Padasuka, Setiamanah, Leuwigajah, dan Melong.

\section{Saran}

Berdasarkan evaluasi ini, wilayah di Kota Cimahi yang berada dalam kategori risiko tinggi maupun sangat tinggi menunjukkan potensi untuk menurunkan kualitas lingkungan yang tentu akan merugikan masyarakatnya. Oleh karena itu, perlu dilakukan strategi atau perencanaan yang disusun atas dasar faktorfaktor yang berpengaruh dalam penilaian risiko air limbah domestik ini. Melalui strategi tersebut, diharapkan dapat menurunkan risiko di wilayah target.

\section{Referensi}

Achmad, S., 2018. Perancangan Algoritma Otomatisasi Normalisasi Data, Bandar Lampung: Universitas Lampung.

Adhi, E. T., 2009. Pelayanan Sanitasi Buruk: Akar dari Kemiskinan. Jurnal Analisis Sosial, pp. 76-87.

Aditama, T. Y., 2014. Panduan Praktis Pelaksanaan EHRA (Environmental Health Risk Asessment)/Penilaian Risiko Kesehatan karena Lingkungan. Indonesia: Kementerian Kesehatan Republik Indonesia.

AMPL, Pokja. 2013. Indeks Risiko Sanitasi: Percepatan Pembangunan Sanitasi Permukiman

Azhar, J., 2016. Penilaian Risiko Kesehatan Lingkungan di Dusun Kokoa Desa Marannu Kecamatan Lau Kabupaten Maros, Makassar: Universitas Islam Negeri Alauddin Makassar.

Dinas Perumahan dan Kawasan Permukiman Kota Cimahi. 2017. Data Air Limbah.

Hartoyo, S., 2018. Pedoman Strategi Sanitasi Kota 2018. Jakarta: Direktorat Jenderal Cipta Karya.

Oche, 2016. Pengolahan Air Limbah Domestik di Kota Cimahi Begitu Rendah. [Online] Available at: https://jabar.pojoksatu.id/bandung/2016/03/03/pengolahan-air-limbah-domestik-dikota-cimahi-begitu-rendah/

Peraturan Kepala Badan Pusat Statistik Nomor 37 Tahun 2010 tentang Klasifikasi Perkotaan dan Perdesaan di Indonesia.

Peraturan Pemerintah Nomor 66 Tahun 2014 tentang Kesehatan Lingkungan.

Priatna, A. M., 2019. Dokumen Informasi Kinerja Pengelolaan Lingkungan Hidup (DIKPLHD) Kota Cimahi Tahun 2019.

Available at: https://cimahikota.go.id/pengumuman/detail/323

Saaty, T. L. 1986. Pengambilan Keputusan. Jakarta: Pustaka Binaman Pressindo.

Sofyan, L., Soewondo, P., Kunaefi, T. D. \& Handajani, M., 2014. Faktor-Faktor Penting Pengelolaan Sanitasi oleh Masyarakat di Kawasan Kumuh Perkotaan Bandung Raya, Bandung: Institut Teknologi Bandung.

Soleh, A. Z., 2005. Ilmu Statistika. Bandung: Rekayasa Sains.

Sutarjo, U. S. 2018. Health Statistics: Profil Kesehatan Indonesia Tahun 2017. Jakarta: Kementerian Kesehatan Republik Indonesia. 